\title{
Mitigation Strategies of the Urban Heat Island Over Greater Cairo Metropolitan Area, Egypt Utilizing ENVI-Met Model
}

\author{
Mona Sayed Hussein \\ Geography Department, Faculty of Arts, Cairo University, Giza, Egypt
}

\begin{abstract}
The formation of urban heat islands (UHI) over cities is the main challenge to the urban environmental sustainability worldwide. To mitigate UHI effects, passive cooling using cool materials and/or greening is thought to be the most effective strategy. As urban greening is relatively nascent in the urban literature, a multitude of research gaps are still to be filled, especially for the cities belonging to the hot arid belt. The present study aims to explore to what extent are three greening strategies (façade greening, roofs greening and urban parks) feasible in UHI mitigation using case study in Greater Cairo Metropolitan Area (GCMA). This task is best achieved through modeling, using the micro-scale numerical model ENVI-met, to simulate the probable outdoor cooling effects of greening for a hot summer day. The results, for this specific case, show that both façade and roof greening would yield up to $0.5^{\circ} \mathrm{C}$ average reduction of air temperature compared with the actual case, while the cooling effects of the hypothetical pocket parks may be as high as $7^{\circ} \mathrm{C}$ during day time till $15.00 \mathrm{PM}$, and after that parks would exhibit heat island properties. The study findings may assist in better planning of urban green spaces to increase their cooling potentialities.

Keywords: ENVI-met; Modeling; Passive cooling; Urban greening; Urban heat island.
\end{abstract}

\section{INTRODUCTION}

One of the current challenges of the urban environmental sustainability is the formation of UHI over cities. UHI is the air temperature difference between an urban space and its surrounding rural areas (Rizwan et al., 2008). The main sustainability measures (human thermal comfort, energy consumption and carbon dioxide emissions) are all strongly related to UHI. UHI and urban pollution island (UPI) are coexisting phenomena as high temperatures accelerate certain atmospheric chemistry cycles (Ulpiani, 2021). Furthermore, the increase in cooling energy consumption to mitigate UHI effects results in more emissions. The rise of both air temperature and the concentration of harmful pollutants severely affect human health, and increase heat-related mortality rates (Santamouris 2016), and the situation is further exacerbated during hot waves. As almost all future climatological scenarios point towards remarkably higher temperatures, there is an increasing global interest in assessing the potential benefits resulting from the UHI mitigation.

To decrease absorption of the solar radiation in urban environments, several passive systems (i. e. function utilizing primary energy sources) were identified and experimented. Nowadays, two main strategies are being implemented: (1) the use of "cool materials" with high solar reflectance as pavement and building envelopes, and (2) the expansion of the vegetative cover, which cause passive cooling through evapotranspiration and provision of shading. The three main greening strategies are: roof greening, façade greening and urban parks. Green roofs are roofs that are fully or partially covered with vegetation. They may be intensive, having a deep soil layer $(0.5 \mathrm{~m})$ to accommodate large plants, or extensive, having a shallow soil layer $(0.2 \mathrm{~m})$ and requiring little irrigation and low maintenance (William et al., 2016, Balany et al., 2020). Green façades (also referred to as vertical greenery; bio-walls; living walls or vertical gardens) have plants attached to walls. The plants can be wallclimbing or hanging-down and may require a speciallydesigned irrigation system. The urban parks increase the water-permeable city surface, thus retaining water in the soil and enhancing evapotranspiration. Additionally, parks are unique in that their cooling effect may extend several hundred meters beyond the park borders. Greening strategies proved to be effective in decreasing energy consumption indoors (Wang et al. , 2014), and achieving thermal comfort, air quality and reducing noise in the outdoors (Desario and Gray 2015, Akbari and Kolokotsa 2016, Takács et al., 2016, Degirmenci et al., 2021, Khare et al., 2021, Stewart and Mills 2021).

As the implementation of greening strategies requires high costs, and in view of the lack of quantitative observational data about the effectiveness of each strategy, researchers have turned to models to explore the outcomes in a variety of scenarios (Crank et al., 2018). Climate models simulate real-world phenomena using equations that link properties (e.g. air temperature) to processes (e.g. transfer of heat). In terms of scale, urban climate models are classified into micro-, local- and mesoscale. The emphasis of microscale models is on the urban canopy layer which extends from ground to the height of buildings and trees. The high complexity of this layer discouraged most meteorologists from studying urban microclimates until it was shown in the 1980s that simplification is possible with relatively little loss of rigor (Oke et al., 2017).

Modeling the potential effects of various greening strategies was primarily investigated through case studies belonging to temperate or continental climates of Europe, Canada, and the United States (e.g. Musco 2016), or tropical climates of Asia as exemplified by Singapore, Hong Kong, and other Chinese cities (Wong and Chen 2016). Despite the fact that UHI effects are more pronounced in the hot arid belt's summer season than elsewhere, just a few studies on urban greening in this belt have been conducted: 
Bencheikh and Rchid (2012) studied the Ghardaia Oasis in Algeria; Hanafi and Djamel (2017) studied Biskra in Algeria; Birge et al. (2019) studied Abu Dhabi, UAE; Abaas (2019) studied Baghdad, Iraq; and Abdulateef and Al-Alwan (2022) studied Baghdad, Iraq; and Jaddah, Saudi Arabia, by Aina et al. (2021), as well as certain Egyptian case studies.

GCMA is the largest world metro belonging to the hot arid belt. With more than 25 million inhabitants and about $450 \mathrm{~km}^{2}$ of built-up area (estimates for the year 2020), the agglomeration witnessed unprecedented expansion during the last decades, overwhelming all the master plans developed before. This state-of-affair results in the intensification of UHI as reported in several studies (Benas et al., 2017, Polydoros et al., 2018, Mahmoud and Gan 2018, El Kenawy et al., 2020. However, for a "case against" see Shahraiyni et al., 2016). The poor quality of the GCMA air is partly due to the fact that the urban developments did not consider urban trees to control the hot climate (Fahmy and Sharples 2008). Realizing the ecosystem services potential of greening, a plan was set in 1990s to establish the $100 \mathrm{~km}$ long by 25 meters wide "Greater Cairo Ring Road Green Belt" (https://www.eeaa.gov.eg/Portals/0/Documents/greenb elt/greenbelt.pdf, accessed April, 18, 2021). But later on, the plan has been shelved in favor of expanding the built-up area. More recently, the vehicular network redevelopments leave the city less green (Elbardisy et al., 2021). Today, the per capita green area in Cairo is as low as 6 square centimeters, and the consumption of electricity for air conditioning is unprecedentedly rising (Aboelata and Sodoudi 2019).

The first study to model the urban microclimate referring to a case from Egypt was published as late as 2008. This study (Fahmy and Sharples 2008) explored the mutual effects between three urban forms (dot, clustered and compact) on one hand and the microclimatic conditions in a case from Cairo on the other. Later on, Fahmy and Sharples (2009) investigated the combined effect of urban geometry and greenery on the thermal comfort using hypothetical case in New Cairo. Further progress was achieved when Fahmy et al., (2010), using leaf area index (LAI), simulated the thermal performance (i. e. interception of direct radiation) of Ficus elastica and Peltophorum pterocarpum in Cairo's summer season. Fahmy et al. (2017) explores the role of green walls and roofs together with trees, in two cases in Metropolitan Cairo and Alexandria. Fahmy et al. (2018) studied the mitigation of UHI using a case in Cairo, with simulation of the present and two future scenarios for 2050 and 2080. Only two greening strategies (tree lines and green roofs) were modeled. Again, Fahmy et al. (2019) modeled two hypothetical cases, in new Cairo and Heliopolis, to study the combined effect of street geometry and greenery. Aboelata and Sodoudi (2019), Aboelata (2020) and Aboelata and Sodoudi (2020) simulate the effects of tree lines strategy to ameliorate microclimate conditions in cases in Cairo, and the same thing was done by Elbardisy et al. (2021) using a case in Heliopolis. In a more narrow application, amelio- rating school microclimate through plantation was presented by Elbardisy et al. (2016) using a case from Metropolitan Cairo.

Recently, Fahmy et al. (2020) reviewed all the case studies on the urban microclimate of Egypt. It is noteworthy that all these studies were: (1) conducted exclusively by architects. Geographers, climatologists and ecologists have never contributed to the subject matter; (2) almost all of them are applied to cases in New Cairo and Heliopolis, and thus leaving the highly dense urban "popular quarters" unexplored; (3) some are mere hypothetical cases to show how a change of geometry of an existing urban setting can mitigate UHI, e.g. rotating an urban canyon $10^{\circ}$ clockwise. Indeed, the findings of such studies do provide invaluable insights into future urban planning in Egypt, but changing the already existing geometries is not a common UHI mitigation strategy worldwide.

Though not intended to model greening strategies, three other studies using cases from Egypt showed that the strategy of geometry manipulation alone cannot mitigate all UHI effects at pedestrian level, as all locations would be vulnerable during the noon hours. Of these, two studies used cases in Cairo and New Aswan (Galal et al., 2020a, b), with recommendation to add vegetation and change surface materials as additional mitigating measures. The third study, on the resort city of Baltim (Limona et al., 2019), is the only one addressing the role of sea breeze, together with three urban forms, in human comfort. They concluded that, even with the most favorable geometry, the heat comfort could not be attained through urban geometry alone.

As a result, as Fahmy et al. (2018) pointed out, there are still a lack of UHI mitigation research in Egypt. One of our significant knowledge gaps is the efficacy of greening walls and/or roofs. Despite the fact that the topic was and continues to be of global interest, the effects of urban parks have never been investigated using Egyptian examples. The current study was sparked by a desire to learn more about parks' ability to alleviate stress, as well as other greening methods. Because most research on examples in Egypt has focused on tree arrangements (street greening), the current study will examine how viable three different greening choices (green roofs, green façades, and urban parks) are for UHI reduction. Modeling is the most efficient way to complete the task, and the findings may be useful to planners.

\section{MATERIALS AND METHODS}

\section{Study area}

The study area is part of GCMA (Figs. 1 and 2). It is rectangular in shape, being $420 \mathrm{~m}$ by $330 \mathrm{~m}$, and is located between $30^{\circ} 01^{\prime} 32^{\prime \prime}$ and $30^{\circ} 01^{\prime} 46^{\prime \prime}$ North and $31^{\circ} 11^{\prime} 57^{\prime \prime}$ and $31^{\circ} 12^{\prime} 16^{\prime \prime}$ East. It is so chosen as to include the two extremes of urban forms, of which the compact form is represented by parts of Abu Qatada and Bein Es-Sarayat quarters, while the campus of Cairo University represents the dot (single building) form. Additionally, the area offers different urban ele- 
ments, including 210 buildings with heights ranging from 3 to $30 \mathrm{~m}$, a wide variety of vegetation (94 trees in the sidewalks and the University campus, and hedge and grass in the campus), and streets and alleys ranging in width between 35 and $5 \mathrm{~m}$. The configurations of the streets and their flanking buildings give rise to different canyon geometries and different canyon orientations to the prevailing wind.

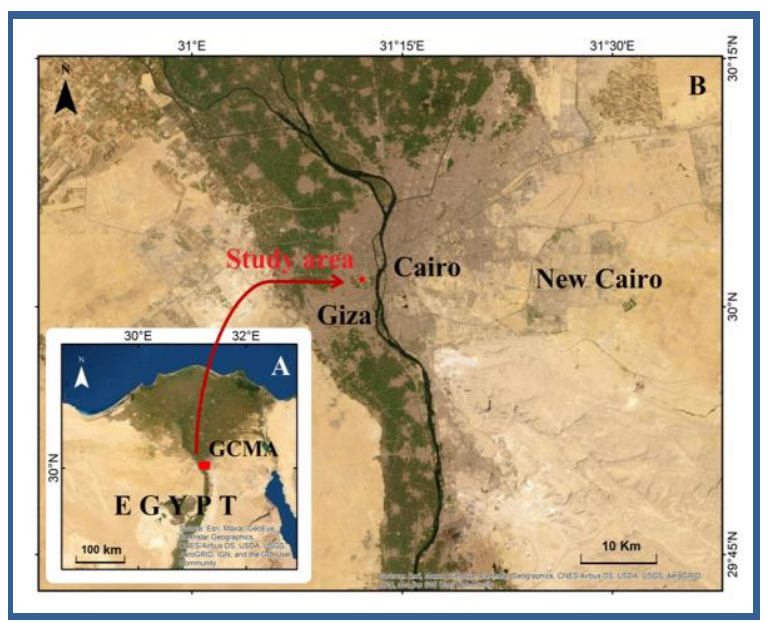

Figure (1): Location of the study area. (A) GCMA bounded by farmlands from north and south, and by deserts from east and west; (B) The study area as part of GCMA.

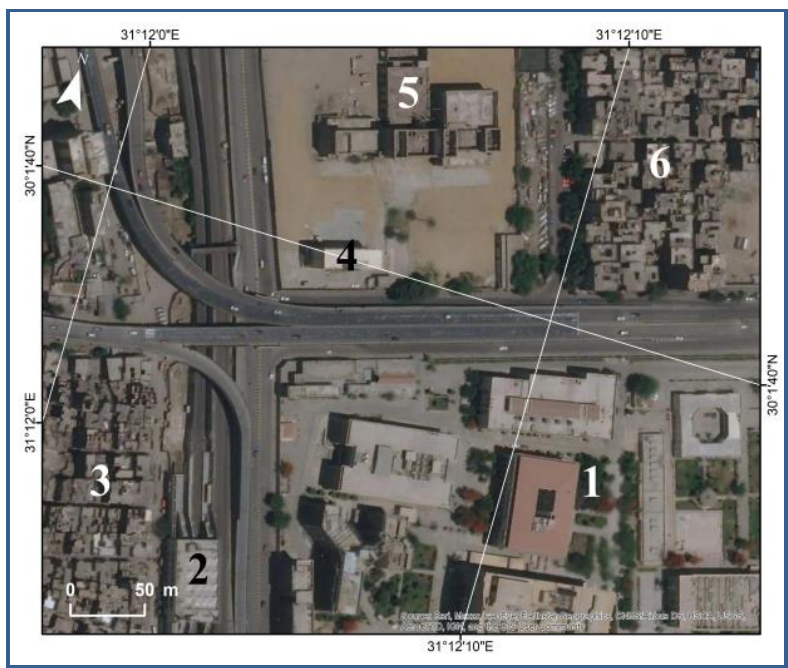

Figure (2): Satellite view of the study area as of April 2021. (1) Cairo University campus (part); (2) Cairo University metro station; (3) Abu Qatada quarter (part); (4) Faculty of Computer Sciences; (5) A heritage brewery (under restoration); (6) Bein EsSarayat quarter (part).

The evolution of the land cover of the study area across the last century is well documented in the "Town series" maps, which is a reduced version of the detailed original cadastral maps. Fig. (3) shows three successive snapshots of the landscape as surveyed in 1930 and 1946 and aerially photographed in 1977. The first snapshot depicts a blue scape of two (now defunct) irrigation canals separating the rural hinterland of Giza (the twin city of Cairo) (west) from its urban margin (east). The margin was still having farmlands inbetween the built-up areas. In the second snapshot the landscape became less green but still having the blue. Lastly, the green was represented only by dotted trees (the small brown circles on the map). The land cover evolution of the study area is not unique, as almost all the rural/urban fringe of the present-day Greater Cairo underwent similar developments.

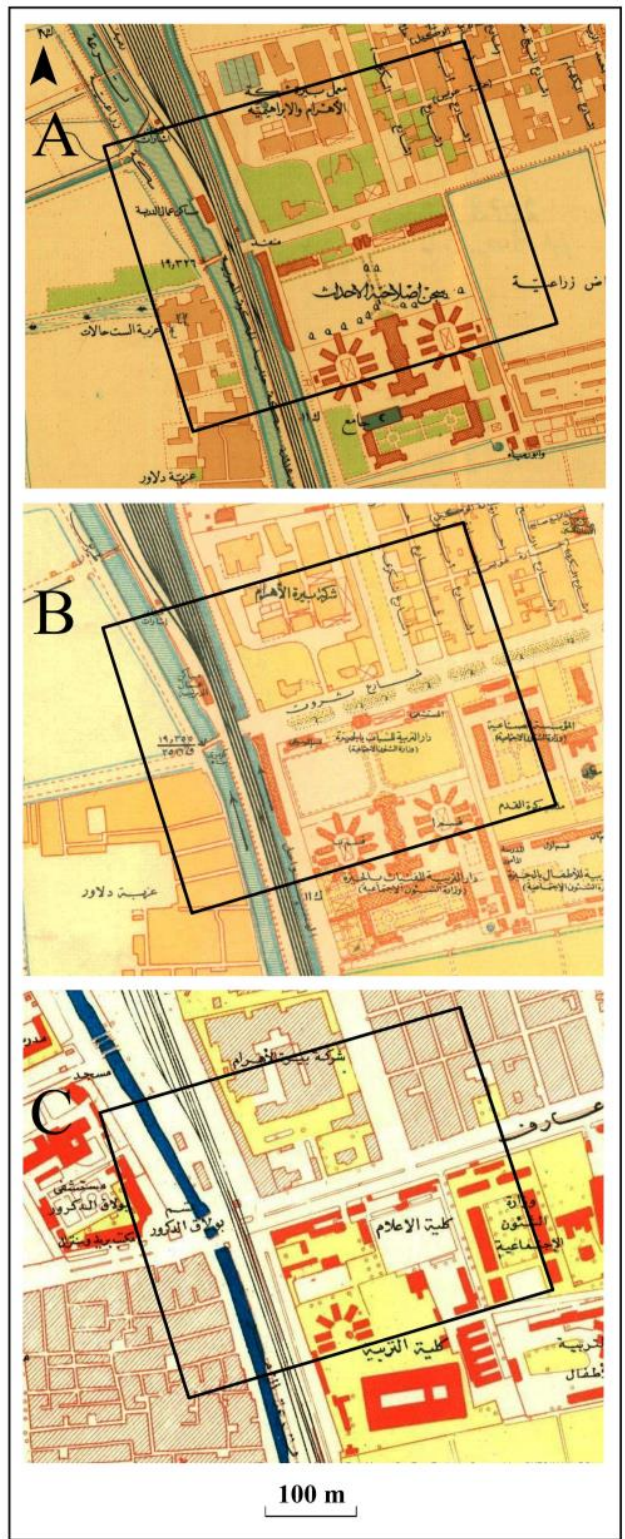

Figure (3): Evolution of the land cover in the study area as documented in old maps: (A) the cadaster of 1930; (B) the cadaster of 1946; (C) the aerial photographs of 1977. Blue refers to two defunct irrigation canals; green to both farmland and urban greenery, orange for residential buildings, and brown for public buildings. Source: adapted from Survey of Egypt 1946, 1959; ESA 1991.

The summer climate is hot and dry, with dominant $\mathrm{N}$ to NW winds with chilling effect. According to the Solar Atlas of Egypt (Ministry of Electricity and Renewable Energy, 2018), the mean surface direct normal irradiance (DNI) in Cairo, is as high as 390 $\mathrm{W} / \mathrm{m}^{2}$ in June and July, while the global horizontal irradiance $(\mathrm{GHI})$ is $350 \mathrm{~W} / \mathrm{m}^{2}$ in both months. The closest meteorological station (Giza agromet) is approximately $1.1 \mathrm{~km}$ south of the research area's centre point. Since 1955, it has been operational. Table (1) shows the climatic normal of air temperature for the last published time series, as published by the Egyptian Meteorological Authority (EMA). 
Table (1): Air temperature $\left({ }^{\circ} \mathrm{C}\right)$ at Giza agromet station throughout the hottest months (1976-2005, EMA (2011).

\begin{tabular}{lccc}
\hline \hline \multirow{2}{*}{ Recorded value } & \multicolumn{3}{c}{ Months } \\
\cline { 2 - 4 } & June & July & August \\
\hline Mean of Max & 34.9 & 35.3 & 34.9 \\
Mean of Min & 21.2 & 22.7 & 23 \\
$\begin{array}{l}\text { Max absolute record in } \\
\text { 30 years }\end{array}$ & 45.8 & 44.9 & 41.6 \\
$\begin{array}{l}\text { Mean at 06:00 local } \\
\text { time }\end{array}$ & 25.1 & 26 & 26 \\
$\begin{array}{l}\text { Mean at 12:00 } \\
\text { Mean at 18:00 }\end{array}$ & 33.9 & 34.3 & 34 \\
\hline \hline
\end{tabular}

\section{Site surveys}

Modeling urban microclimate requires that meteorological and spatial data on the built environment are brought together. The spatial data describe the geometry of streets and buildings, the materials of buildings, pavements and soil. The described data were compiled during field studies in March and April 2021.

\section{Field measurement of meteorological data}

Typically, the last week of June and the first of July are the extreme hot weeks of the summer of Egypt. Accordingly, the field measurements were conducted for the hottest 8-hours (between 10.00 and 18.00 local time) on Friday June, 25, 2021. Being public holiday, Fridays witness the least heat and exhaust emissions. Following the guidelines set by World Meteorological Organization (Oke, 2006), air temperature (Ta) and relative humidity $(\mathrm{RH})$ were measured in two sheltered observation points (Points A and B Fig. 4) using UT330B USB data logger with $0.1^{\circ} \mathrm{C}$ resolution and $\pm 0.5^{\circ} \mathrm{C}$ accuracy. The measurements, shown in Table 2 , were taken at $2 \mathrm{~m}$ height, and the loggers were housed in a ventilated shelter so as to be less influenced by winds while their temperature is in equilibrium with the adjacent air.

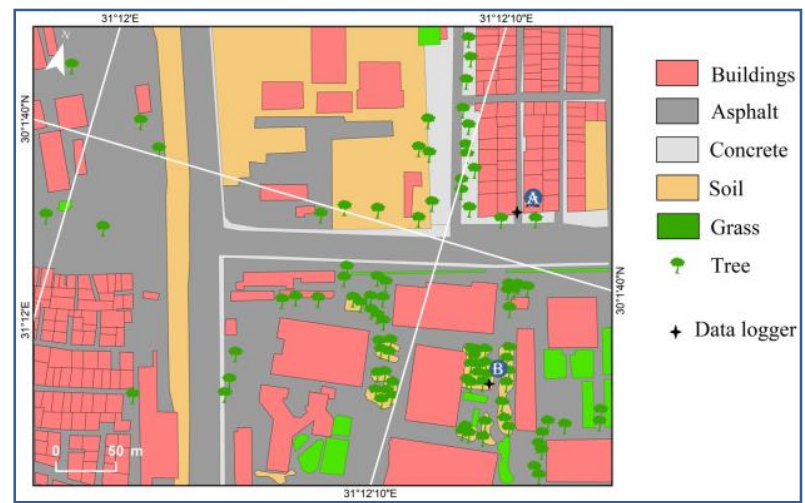

Figure (4): The present land cover in the study area A and B (as of April 2021).

\section{The selected model}

The simulation was performed using version 4.0 of ENVI-met software, which was developed by Michael Bruse in 1994, and has continued to be developed since then. ENVI-met is a computational fluid dynamics (CFD) model. CFD is a numerical method of modeling complex fluid flow by breaking down geometry into cells then computing the fluid flow for the individual cell (Georgatou and Kolokotsa 2016). ENVI-met allows the user to perform one-dimensional steady flow, and one and two-dimensional unsteady flow simulations, with resolution ranging between 0.5 and $10 \mathrm{~m}$ in space and $5 \mathrm{sec}$ in time. The model is mainly used to simulate urban environments and to assess the effects of green architecture visions (official website https://www.envi-met.com/). It consists of 1D boundary model, used for the initialization of the simulation and definition of the boundary conditions, 3D atmospheric model, a soil model, and a vegetation model which simulates the heat and vapor exchanges between the plants and the atmosphere (Tsoka et al. 2018).

The simulation results are visualized in the "Leonardo" module through which users can customize and export the microclimate datasets as maps, or tables containing the co-ordinates of each cell and the values contained in each. Of the possible manipulations of data in Leonardo are map algebra operations. This concept has a long tradition in the works of landscape architects, but the automation of the operations were made available only as late as 1970 s, thanks to the works of Dana Tomlin and the development of the GIS software. Map algebra operations include-among other things-arithmetic operations such as adding and subtracting all cells in a raster layer from the corresponding cells of another layer, and the result would be a new layer. Thus, the cooling effect of a certain greening strategy can be calculated by conducting simple subtraction operation on two layers, one representing the present case and the other being the modeled case, both layers should represent the same areal extent.

The simulations using ENVI-met may take days using PC, and there is no possibility to simulate more than a representative day in a small area. Notwithstanding all its limitations, the use of ENVI-met in microclimate simulations has been increasing signifycantly during the last decade (Balany et al. 2020). In a review of literature on heat-mitigation strategies for the period 1977-2020, Nasrollahi et al. (2020) reported that ENVI-met was the software used in $68 \%$ of all simulations.

Table (2): Measured air temperature (Ta) and relative humidity $(\mathrm{RH})$ values, during the hottest hour of the day at sites $\mathrm{A}$ and $\mathrm{B}$ at $2 \mathrm{~m}$ altitude.

\begin{tabular}{|c|c|c|c|c|}
\hline \multirow{3}{*}{$\begin{array}{c}\text { Hottest } \\
\text { hours in } \\
\text { day }\end{array}$} & \multicolumn{4}{|c|}{ Studied sites } \\
\hline & A & $\mathrm{B}$ & $\mathrm{A}$ & $\mathrm{B}$ \\
\hline & \multicolumn{2}{|c|}{$\mathrm{Ta}\left({ }^{\circ} \mathrm{C}\right)$} & \multicolumn{2}{|c|}{$\mathrm{RH}(\%)$} \\
\hline 10:00 & 31.4 & 31.9 & 56 & 55 \\
\hline 11:00 & 32.4 & 32.8 & 50 & 50 \\
\hline $12: 00$ & 33.7 & 33.7 & 45 & 48 \\
\hline $13: 00$ & 35.6 & 34.4 & 42 & 45 \\
\hline $14: 00$ & 35.7 & 34.4 & 43 & 46 \\
\hline $15: 00$ & 35.6 & 34.4 & 44 & 47 \\
\hline $16: 00$ & 35.0 & 33.7 & 49 & 51 \\
\hline $17: 00$ & 31.8 & 30.0 & 55 & 57 \\
\hline 18:00 & 30.7 & 29.1 & 54 & 59 \\
\hline
\end{tabular}




\section{Model setup and parameterization}

ENVI-met model requires an area input file (.INX) which defines the 3D geometry of the area. This file was created in "Spaces" module using a bitmap file (bmp) of the land cover map (Fig. 4). The walls of buildings were all assumed to be made of red brick while the roofs are made of concrete. The streets are of asphalt while most of the narrow sidewalks (which are made of concrete) could not be represented in view of the selected resolution. As recommended by the developer, a compromise has to be found between the accuracy and resolution of the model, otherwise the model may require several days to perform the computations. Accordingly, the $420 * 330 \mathrm{~m}$ modeled area was fitted into $84 \times 66$ grid cells of $5 \times 5 \mathrm{~m}$ each. In order to ensure a stable numerical simulation and minimize errors at the model boundary, 10 nesting grid cells were added around the core area. As the default model orientation is that $\mathrm{Y}$-axis pointing to north, the model was rotated $-16^{\circ}$ (i. e. counterclockwise) away from grid north so as to align almost all streets and buildings' layouts to the $\mathrm{X}$ - and/or $\mathrm{Y}$-axis and thus better representing street canyons.

As the tallest building is $30 \mathrm{~m}$ high, the model upper boundary was set as $90 \mathrm{~m}$. This $\mathrm{z}$ parameter is digitally represented by 30 vertical grid cells with $3 \mathrm{~m}$ each. The vertical datum was set as zero, and there was no need for a digital elevation model (DEM) as the topography of the area is almost flat. The main input data are shown in Table (3). No parameters were input for the building materials as they are already defined in the ENVI-met database. The other windows had their values kept as standard.

Table (3) Main input data used for ENVI-met, air temperature (Ta); relativite humidity $(\mathrm{RH})$; wind speed (WS); wind direction (North West, NW); sky cover; soil humidity at different depths.

\begin{tabular}{cc}
\hline \hline Measured parameters & Recorded value \\
\hline Air temperature $\left({ }^{\circ} \mathbf{C}\right)$ & \\
Max Ta & 35.9 , at 13:40 \\
Min Ta & 24.2 , at 04:00 \\
Relative Humidity (\%) & \\
Max RH & 72 , at $03: 30$ \\
Min RH & 42, at $13: 00$ \\
WS at 10m height $(\mathbf{m} / \mathbf{s})$ & 4.2 \\
Wind direction $(\mathbf{N W})$ & $315^{\circ}$ \\
Sky cover & 0 \\
Soil humidity $(\%)$ & \\
Soil depth $0.0-50 \mathrm{~cm}$ & 25.00 \\
Soil depth $50-200 \mathrm{~cm}$ & 30.00 \\
\hline \hline
\end{tabular}

In "Envi guide" module used for performing the simulation, the "Simple forcing" option for temperature and humidity was used to avoid computation problems, as recommended by the developer (https://envimet.info/doku.phpid=kb:lbc). The simulations were held for 8-hours, between 10.00 and 18.00 local time, on June, 25th as one of the extreme hot days of summer. Four scenarios were simulated: (1) Actual case, with the present vegetation cover; (2) Façade greening case, using the option "only green" (i. e. without substrate); (3) Roof greening case, using the options "green, sandy loam substrate" and "greening without air gap"; (4) Introducing two hypothetical pocket parks with dense crown trees, each is $10 \mathrm{~m}$ apart. The methodology used is summarized in Fig. (5).

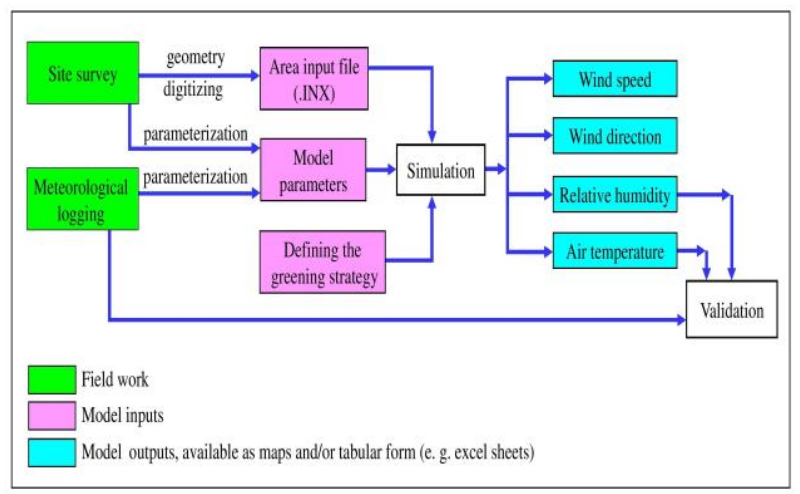

Figure (5): Flowchart of the methodology used.

\section{RESULTS AND DISCUSSION}

\section{Site surveys}

As the area is a principal crossroads, it is not surprising that the pavement materials, of asphalt and concrete, account for more than half of the land cover (Fig 4 and Table 4), not including the flyovers. The pavement contributes to the development of UHI. The relatively high percentage of soil cover is due to both the planted areas in the university campus and the earthen bank on which a major railway was laid down.

Table (4): The lands cover types' proportions in the study area. As represented: B, building; As, Asphalt; and Con, concrete coverage area $\left(\mathrm{m}^{2}\right)$.

\begin{tabular}{cccccc}
\hline \hline $\begin{array}{c}\text { Land } \\
\text { cover }\end{array}$ & B & As & Con & Soil & Total \\
\hline $\begin{array}{c}\text { Area } \\
\left(\mathbf{m}^{2}\right)\end{array}$ & 41,130 & 63,116 & 7,296 & 27,058 & 138,600 \\
$\%$ & 29.7 & 45.5 & 5.3 & 19.5 & 100 \\
\hline \hline
\end{tabular}

The urban form in the north east and south west is of the compact type, the so-called Arabian or Saharan, which is characterized by the narrow alleys (down to $5 \mathrm{~m}$ or even $4 \mathrm{~m}$-wide) (Fig. $6 \mathrm{~A}, \mathrm{~B}, \mathrm{C}, \mathrm{D})$. This traditional form was intended to provide shade in the arid climate environments (Hassan et al., 2016) though it minimizes wind chilling potential. In the south east, the dot urban form of Cairo University (Fig. 6 E, F) prevails. This form increases heat gain from four façades but maximizes wind chilling. Within the compact NE block, the streets are oriented N-S so as to maximize the flow of cool air from $\mathrm{N}$ and $\mathrm{NW}$, and to provide shading through the block by buildings of solar radiation before and after the noon. Contrarily, the SW compact block is not so fortunate, as its alleys are E-W oriented, with less shading and less air chilling potentials. The reason is that this neighborhood was originally established as a hamlet amid the farmlands, and thus the alleys had had to be perpendicular to the main dirt road, itself the left bank of the then existing 
irrigation canal (see Fig. 3A). In both two blocks, few buildings are only $6 \mathrm{~m}$ tall, but most of them are taller enough, on either side on the streets, to create urban canyons with high values of aspect ratio (H/W, buildings mean height/ street width) and low sky-view factor (SVF), or less openness to the sky. This geometry contributes well to the shading effect, and thus improves the human thermal comfort during the hot season. However, the main canyon is a wide street oriented E-W, with unfavorable geometry in terms of both $\mathrm{H} / \mathrm{W}$ and SVF.
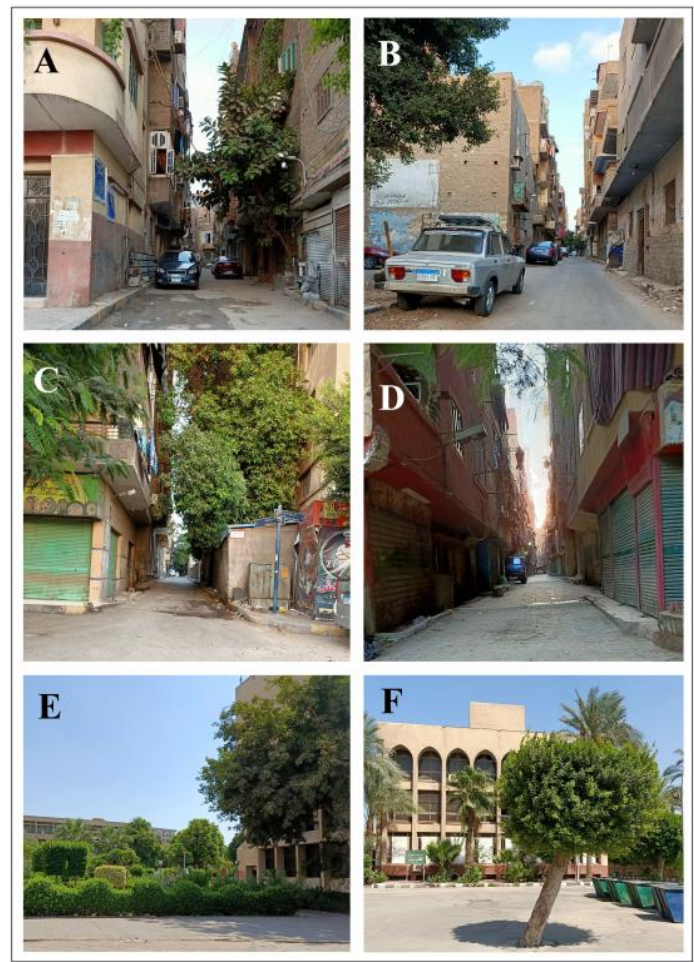

Figure (6): Photographs of urban components in the study area: (A) and $(\mathrm{C})$ showing the alleyways are narrow, the tree-shading approach successfully doubles as façade greening, Bein El-Sarayat quarter; (B), Typical north-south urban canyon, Bein El-Sarayat quarter; (D), Typical east-west urban canyon, Abu Qatada quarter. Note the sun rays about 2 hours after sunrise; (E) The many types of greenery on the Cairo University campus; $(\mathrm{F})$, A tree on the Cairo University campus with a tiny shaded area at 13.35 at local time on June 25, 2021, when the sun was 67 degrees above the horizon.

The current greenery coverage ratio (GCR) is $5.8 \%$ (Table 5). In the narrow alleys, some trees act as wall greenery, though not originally intended to be so (Fig. $6 \mathrm{~A}$ and $\mathrm{C}$ ). However, trees cultivated around are mostly with dense crown, but some of them are less dense and practically ineffective for microclimate amelioration (Fig. 6F).

\section{The Simulation of the four scenarios}

Before conducting any simulation, ENVI-met provides the opportunity to have a look to the modeled area as 3D block diagram. Fig. 7A shows the 3D used for simulating three of the four scenarios: the actual case, façade greening and roof greening, while Fig. 7B shows the modeled area after introducing two hypothetical pocket parks with dense crown trees, each is $10 \mathrm{~m}$ apart. The largest park is 2.0 hectare area, and is now a vacant plot with some old unused buildings, while the smallest one is only 0.35 ha, and is supposed to replace a block consisted of 42 buildings.

Table (5): Coverage of all greenery types

\begin{tabular}{lccccc}
\hline \hline Coverage & $\begin{array}{c}\text { Study } \\
\text { area }\end{array}$ & $\begin{array}{c}\text { All } \\
\text { greenery } \\
\text { types }\end{array}$ & Grass & Hedge & Trees* \\
\hline Area $\left(\mathrm{m}^{2}\right)$ & 138,600 & 8,093 & 1,590 & 126 & 6,377 \\
$\%$ & 100 & 5.8 & 1.1 & 0.1 & 4.6 \\
\hline \hline
\end{tabular}

* canopy extent according to satellite views (as of April 2021) with $60-\mathrm{cm}$ resolution.

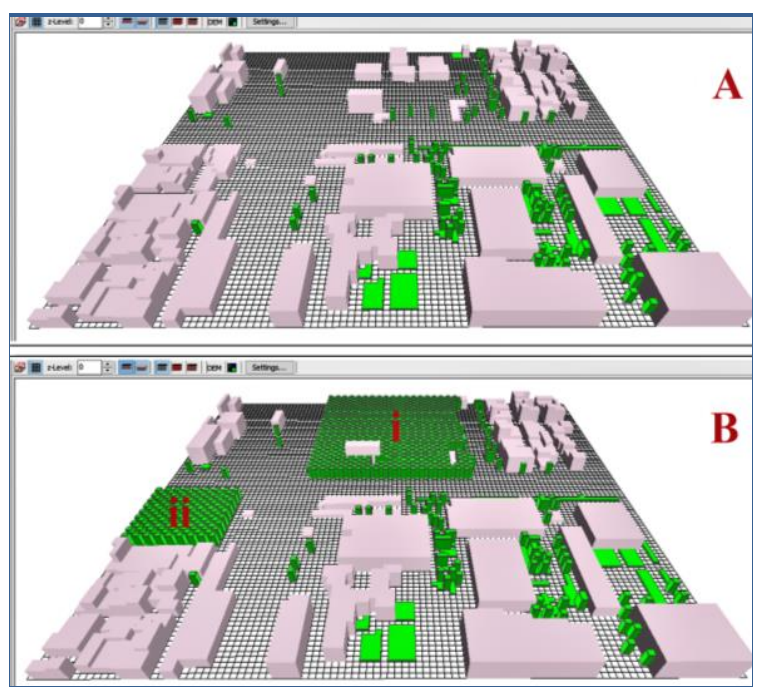

Figure (7): 3D model of the study area created by ENVI-met before the nesting grids were added. (A) Actual situation; (B) introducing two hypothetical pocket parks (i) and (ii).

The simulated Ta values in the four scenarios, down to 0.50 resolution, are shown in Fig. (8). Wind speed, RH outputs are not shown and will be used only for interpretation of $\mathrm{Ta}$ results. Using map algebra, the cooling (and warming, if any) effect of the three greening strategies is obtained by subtracting layers. Fig. 9 shows, down to $1.0^{\circ}$ resolution, the probable cooling (and warming) effect of the strategies.

\section{Effectiveness of Façade greening strategy}

If strictly applied in accordance with the model parameters, façade greening would yield 0.2 to $0.5^{\circ} \mathrm{C}$ average reduction of $\mathrm{Ta}$ (with standard deviation 0.3 to $0.5^{\circ} \mathrm{C}$ ) compared with the actual case, as shown in Fig. (9) and Table (6). Note that the equation decrease of $T a$ = modeled Ta-Ta actual case holds only for the row containing the average, but seemingly not holds for the rows of Min and Max. This is logical and quite expected, as the cell containing the Min (or Max) value of Ta actual case layer would not necessarily be the same cell containing the Min (or Max) value of the modeled Ta layer.

The results could not be adequately compared with other cases since the number of available studies worldwide is few, as reported in a recent review (Balany et al., 2020). However, in a comparable case belonging to the hot dry climate of Cairo, modeling façade greening yielded slight increase in canyon Ta (Fahmy et al., 2017). In view of the lack of experiments in controlled conditions, the only possible 
interpretation has to refer to the changes in the controls of the received and reflected short-wave radiation. The controls of received radiation are: sun geometry (altitude and azimuth), atmospheric transmissivity, and surface geometry (slope and aspect), while reflection is controlled by surface reflectivity or albedo (Mills et al., 2021). As the albedo is the only control changed, it can be concluded that green façades, through reflection of solar radiation, ameliorate the microclimate indoors (indoors is beyond ENVI-met capabilities, and is not intended to be dealt with here) but not so do in the canyons at the pedestrian level. Also, Fig. (9) shows that the cooling effect for 12:00 and 14:00 for the same greening scenario is almost similar, while at 16.00 is different. This may suggest that the variations of sun elevation would be the control. Calculating sun elevation in NOAA Solar Calculator (https://gml.noaa.gov/grad/solcalc/) for the day of simulation yields 83.3, 62.1 and 36.2 degrees up from the horizon at $12.00,14.00$ and 16.00 respectively. This cannot account for the similarity at 12:00 and 16:00. For the same day, sun azimuth (measured in degrees clockwise from north) was 176, 263 and 278, respectively, and thus cannot account for the variability between 12:00 and 14:00 on one hand and 16:00 on the other.

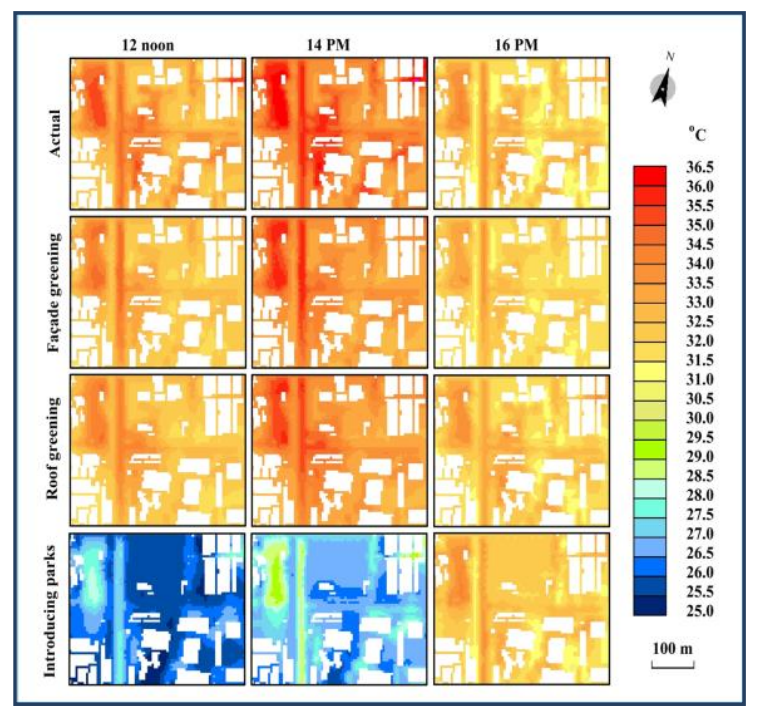

Figure (8): Modeled air temperature values of four scenarios at $1.50 \mathrm{~m}$ above ground.

\section{Effectiveness of roof greening}

Green roofs are often considered as the most suitable urban greening strategy where open spaces are limited (Balany et al., 2020), as is the case with the study area. However, the results for the roof greening scenarios (Fig. 9 and Table 7) are almost similar to those of façade greening (vide supra). These results are in accordance with the findings in other studies, which have shown that green roofs give a very low improvement or even no improve to the level of thermal comfort, at the pedestrian level (Santamouris 2014, Balany et al., 2020). Even indoors, roof greening was found to be of low effectiveness in three cases belonging to three climatic zones in Egypt: Alexandria, Cairo and Aswan (Mahmoud and Ismaeel 2019). However, the subject is still a research gap for hot arid climates as reported in a very recent review (Jamei et al., 2021).

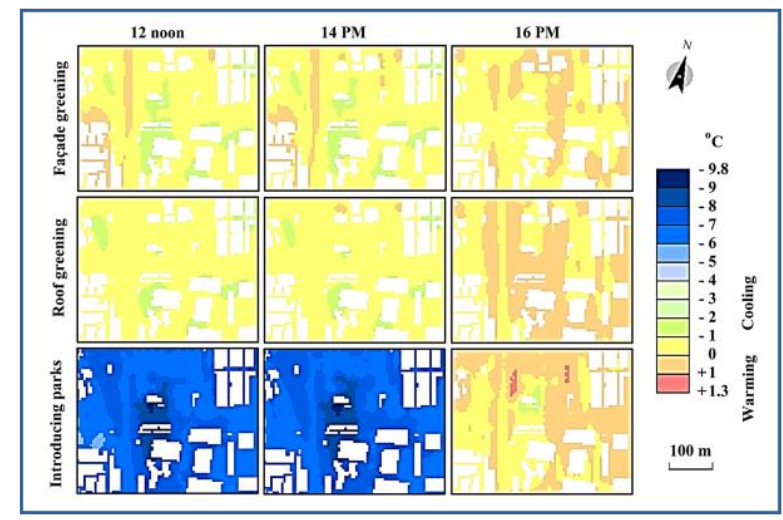

Figure (9): Modeled cooling effect of three greening techniques at $1.50 \mathrm{~m}$ above ground (positive values denote warming). Buildings are supposed to be non-existent in place of the two imagined parks.

\section{Effectiveness of parks}

Strangely enough, parks have never been proposed as a possible strategy to mitigate UHI in Egypt. Though the literature on the cooling effects of parks is ample, very few studies on hot arid climate cases have been done. Indeed, most of the Egyptian cities which are plagued by UHI have no vacant spaces to be used for planting parks within the built-up area. However, introducing pocket parks is still possible without largescale redevelopment.

To model the anticipated cooling effects of pocket parks, the two hypothetical parks shown in Fig. (7B) were used. Unlike the results of façade and roof greening, Fig. (9) and Table (8) show that parks can help to moderate UHI during the day until 15.00 PM, after which they will experience air warming even under the canopy of vegetation. These results are in agreement with the well-established conclusion that parks are cooler during the day and are warmer during the night (Bowler et al., 2010). However, in the present case study the warming effects started at 15.00, well earlier than the supposed time of sunset (19.01 PM for the day of simulation). Also, the results show that the extension of the cooling effect is beyond the model's boundaries, and thus it cannot be predicted. This result is in disagreement with the rule of thumb that the cooling effect would extend approximately the distance of the park's width.

The high diversity, of the possible park geometries and size, results in varying magnitudes and transport of cooling (Gunawardena et al., 2017). Additionally, the plant architecture (canopy form, foliage density, branch systems) and plant physiology (which depends on species, age and health) result in a range of microclimates that defies simple generalization (Oke et al., 2017, Roth 2020). Anjos and Lopes (2017) reviewed the studies conducted in seven cities with park size ranging from 500 to 0.24 hectares, and they reported cooling effects ranging from 1 to $3^{\circ} \mathrm{C}$. Contrarily, Jaganmohan et al., (2016), upon studying a case belonging to the temperate climate, found that small-sized parks with complex shapes may result in 
Table (6): Actual air temperature (Ta) and estimated Ta owing to three modeled greening designs, in which Ta has decreased (the positive value refers to warming).

\begin{tabular}{|c|c|c|c|c|c|c|c|}
\hline & \multirow{2}{*}{ Category } & & \multicolumn{5}{|c|}{ Air temperature (Ta) } \\
\hline & & & Local time & Average & Min. & Max. & \pm SD \\
\hline \multirow{21}{*}{$\begin{array}{c}\text { Hypothetical } \\
\text { design }\end{array}$} & \multirow{3}{*}{\multicolumn{2}{|c|}{ Actual case }} & $12: 00$ & 33.2 & 31.7 & 35.7 & 0.9 \\
\hline & & & $14: 00$ & 34.2 & 32.6 & 36.5 & 0.9 \\
\hline & & & $16: 00$ & 32.3 & 30.8 & 34.1 & 0.7 \\
\hline & \multirow{6}{*}{$\begin{array}{c}\text { Façade } \\
\text { greening }\end{array}$} & \multirow{3}{*}{$\begin{array}{c}\text { Modeled } \\
\text { Ta }\end{array}$} & $12: 00$ & 32.7 & 31.7 & 35.0 & 0.7 \\
\hline & & & $14: 00$ & 33.8 & 32.6 & 36.0 & 0.8 \\
\hline & & & $16: 00$ & 32.1 & 31.2 & 33.5 & 0.5 \\
\hline & & \multirow{3}{*}{$\begin{array}{c}\text { decrease } \\
\text { of Ta }\end{array}$} & $12: 00$ & -0.5 & 0.5 & -2.9 & 0.5 \\
\hline & & & $14: 00$ & -0.5 & 0.6 & -2.8 & 0.5 \\
\hline & & & $16: 00$ & -0.2 & 0.8 & -1.1 & 0.3 \\
\hline & \multirow{6}{*}{$\begin{array}{c}\text { Roof } \\
\text { greening }\end{array}$} & \multirow{3}{*}{$\begin{array}{c}\text { Modeled } \\
\text { Ta }\end{array}$} & $12: 00$ & 32.7 & 31.6 & 34.5 & 0.7 \\
\hline & & & 14:00 & 33.8 & 32.6 & 35.8 & 0.7 \\
\hline & & & $16: 00$ & 32.3 & 31.0 & 34.2 & 0.7 \\
\hline & & \multirow{3}{*}{$\begin{array}{c}\text { decrease } \\
\text { of Ta }\end{array}$} & $12: 00$ & -0.5 & 0.6 & -2.9 & 0.4 \\
\hline & & & $14: 00$ & -0.5 & 0.7 & -2.8 & 0.4 \\
\hline & & & $16: 00$ & 0 & 1.5 & -0.9 & 0.3 \\
\hline & \multirow{6}{*}{$\begin{array}{l}\text { Introducing } \\
\text { parks }\end{array}$} & \multirow{3}{*}{$\begin{array}{c}\text { Modeled } \\
\text { Ta }\end{array}$} & $12: 00$ & 26.2 & 25.0 & 29.0 & 0.7 \\
\hline & & & $14: 00$ & 27.1 & 25.8 & 30.0 & 0.8 \\
\hline & & & $16: 00$ & 32.3 & 30.9 & 34.1 & 0.6 \\
\hline & & \multirow{3}{*}{$\begin{array}{c}\text { decrease } \\
\text { of Ta }\end{array}$} & $12: 00$ & -7.0 & -5.6 & -9.8 & 0.6 \\
\hline & & & $14: 00$ & -7.1 & -5.8 & -9.6 & 0.6 \\
\hline & & & $16: 00$ & 0.0 & 1.2 & -1.3 & 0.3 \\
\hline
\end{tabular}

Negative value, is referring to cooling.

warming. This result was confirmed in a recent review (Yu et al., 2020) that found that a small park may behave as heat island, that the threshold-size for cooling is still uncertain, and that the controversial results of the cooling effect need to be further investigated. However, most of the abovementioned conclusions are not related to hot arid climate cases.

As recently noted in a review article (Kerishnan 2021), the growing research on pocket parks is strongly biased in terms of geography. A rare experimental study on the hot dry conditions of Ghardaia, Algeria (Bencheikh and Rchid 2012) reported a $5^{\circ}$ to $10{ }^{\circ} \mathrm{C}$ cooling effect of palm grooves compared with the vicinity. Simulations of park cooling effect during an extreme heat event using an early version of ENVI-Met (Declet-Barreto et al., 2013) yielded a net cooling of air, in and around the park, ranging from $0.9{ }^{\circ} \mathrm{C}$ to $1.9{ }^{\circ} \mathrm{C}$ during the warmest time of the day.

For the present case study, no simple interpretation for the cooling effects, followed by warming, can be presented, as it involves complex interplay of several factors, of which the drag forces of canopies is the most important factor. The drag decreases wind speed and thus reduce the potential for any wind driven cooling. To calculate the amount of decrease, the Leo-nardo module of the software was used to perform layers' subtraction, with all layers customized to give results for $1.5 \mathrm{~m}$ above ground. The results for 12.00 noon show that the decrease is considerable, being $1.9 \mathrm{~m} / \mathrm{s}$ in the center point of the larger park. The map of wind speed for the actual case gives $2.2 \mathrm{~m} / \mathrm{s}$ for the same point, while the map of the parks scenario gives $0.3 \mathrm{~m} / \mathrm{s}$ underneath the canopies. However, the wind would gain momentum immediately after leaving the park, as evidenced by the wind speed in the main east-west canyon, which have decreased to $1.7 \mathrm{~m} / \mathrm{s}$ (parks scenario) from $2.0 \mathrm{~m} / \mathrm{s}$ (actual scenario). Very similar wind speed results were obtained for 14:00 and 16:00. Field verification for the drag forces of canopies is still an extremely difficult, if not impossible, task to achieve, as all the available digital anemoscopes are sensitive only to the wind speed within the range of $2 \mathrm{~m} / \mathrm{s}$ to $30 \mathrm{~m} / \mathrm{s}$.

The pervasive cooling that extends beyond the model boundaries (for 12.00 and 14.00 cases) can be interpreted as that the tree wind blockage effects (leading to warming) are counterbalanced, and even overwhelmed, by the trees evapotranspiration and shade provision (cooling). However, evaporation would be suppressed as RH increases, which is depend-ent in turn on the soil moisture content (a factor that depends on the irrigation and management policies). Other factors that could complicate any interpretation include the fact that stomatal closure at peak temp-eratures prevents further cooling, and the interaction of a non-transpiring tree with radiation can increase air temperature (at $2 \mathrm{~m}$ ) by up to $1.6-2.1^{\circ} \mathrm{C}$ during specific hours of the day. This is consistent with Meili's hypothesis of partially counteracting the evapotranspirative cooling effect (Meili et al., 2021). Mean-while, he added that partitioning the specific tree affects is difficult and impossible to achieve only from observations.

The relation between the shape of the park and the ex- 
tension of the cooling effect cannot be discussed for the present model, as the extension is beyond the model boundaries. This topic is still perplexing. Jaganmohan et al. (2016) reported the "quite surprising" result that an increase in tree coverage reduces the cooling distance, and that a smaller green space with irregular shape provides a longer interface with its surroundings, thus allowing for more cool air to be transported away.

\section{Model validation}

The complex calculations involved ENVI-met on large number of variables makes the validation difficult (Ayyad and Sharples 2019). The first comprehensive evaluation of ENVI-met for handling UHI mitigation strategies worldwide have been conducted by Crank et al (2018). They raise concerns regarding the usefulness of the model, particularly when applied at roof level. However, to the best of the author's knowledge, all the studies conducted on cases in the hot arid and semi-arid climates reported overall good agreements between the modeled and observed values of Ta, and to slightly less agreement for wind speed and RH (e. g. Elnabawi 2015 for Cairo; Ayyad and Sharples 2019 for Amman; Bande et al., 2019 for Abu Dhabi; Aboelata and Sodoudi 2019 for Cairo).

To validate the modeled results of the present study, in situ measurements of $\mathrm{Ta}$ and $\mathrm{RH}$ in the two monitoring points A and B are used. Fig. (10) shows the observed and measured values of $\mathrm{Ta}$ at both points. Through most of the time interval under consideration, the modeled values are lower than the logged ones by an average difference of $1.3^{\circ} \mathrm{C}$ for point $\mathrm{A}$ and $1.4^{\circ} \mathrm{C}$ for $\mathrm{B}$. However, during the two hours before sunset, the simulated values are higher, and Ta modelled data showed an overall agreement with observed data, with an index of agreement of 0.89 and 0.86 for the studied area (point $\mathrm{A}$ and $\mathrm{B}$ respectively). $\mathrm{RH}$, on the other hand, had a weaker agreement, with $\mathrm{A}$ and $\mathrm{B}$ scoring 0.71 and 0.68 , respectively.

\section{Limitations of the study}

The probable cooling effects revealed by the study cannot be 'translated' into thermal comfort potential, both indoors and at the pedestrian level, at the moment. As Fahmy et al. (2020) put it; the global thermal comfort indices used in the Egyptian case studies might not express human comfort for the hot arid climate of Egypt. They stressed on the need for customizing a thermal comfort index, and even different indices for the eight bioclimatic zones of Egypt. As a consequence, other environmental sustainability measures, such as energy consumption and carbon emissions, cannot be calculated, as energy consumption (and potential savings) is mainly related to the thermal comfort.

Other limitations are related to the tool used and the measurements taken in the field. Though ENVI-met is a reliable simulation tool, it is limited in terms of domain size. Hence, it is usually used to model the climate at the micro scale. The fact that cooling at the micro scale may result in warming (and enhancing pollution) at the local scale, as suggested by several studies, limits the usefulness of micro-scale models. Furthermore, a modeling problem specific to the study area was that the fly-

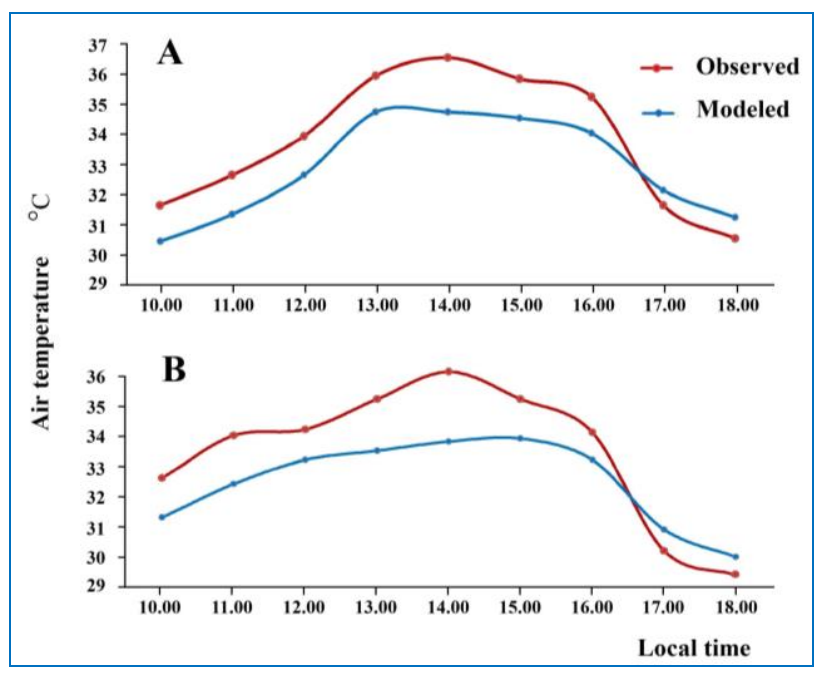

Figure (10): modeled vs. observed values of Ta at $1.5 \mathrm{~m}$ above the ground at the two monitoring points $\mathrm{A}$ and $\mathrm{B}$.

overs depicted in the satellite imagery (Fig. 2) could not be modeled in ENVI-met. Additionally, the model does not account for the effects of vehicles' exhaust. Added to these limitations is that the Ta measurements were within $+/-0.5^{\circ} \mathrm{C}$ accuracy.

\section{Implications for future research}

Heat island is a phenomenon occurring at three scales, giving rise to surface UHI, canopy-layer UHI and boundary-layer UHI (Costanzo et al., 2021). A good understanding of canopy-layer UHI necessitates the coupling of more than one model to ensure that the probable benefits achieved at the canopy-layer scale would not exacerbate the situation at boundary-layer scale. At the micro scale, coupling indoor and outdoor modeling is necessary to obtain comprehensive rather than fragmentary assessments. Coupling indoor-outdoor has already been a research strategy in the Egyptian context starting from the work of Fahmy et al. (2009), but very few of such studies have been achieved to date. Another research gap to be filled is the assessment of the effects of green and blue infrastructure lumped together, on which Ayad et al., (2019) conducted the only published study on an Egyptian case.

As the assessment of greening strategies is still almost a monopoly of architects, worldwide and especially in Egypt, botanists and ecologists are invited to fill the gaps best suited to them. Admittedly, botanists can find the optimal planting scheme, and can assess the multifaceted environmental impacts of the various plant species. They can build on the inventory of street trees in Greater Cairo, already available in three studies (Abd El-Ghani et al., 2011, Abd El-Ghani et al., 2015, Elmasry 2014). A research gap to be filled is the assessment of xeriscaping to reduce urban water use.

The impacts of greening strategies are far beyond what can be quantitatively modeled. Greening improves the environment in other aspects including acoustics, aesthetic values and human physical and mental health. All these aspects are still practically unexplored. A rare empirical study showed that the green façade enhances human physiological and psychological relaxation (Elsadek et al., 2019). 


\section{CONCLUSION}

The study investigates the feasibility of three greening strategies for the mitigation of the canopylayer UHI over GCMA, using a case comprising the two main prevailing urban forms; the compact and the dot. For this specific case, the simulation results using ENVI-met show that façade greening and roof greening are of very limited mitigating effects at the pedestrian level. Contrarily, the hypothetical pocket parks prove to be of good potentialities during the hottest time of the day. However, many aspects of the cooling effects of parks are still uncertain and unexplored worldwide. For a hot dry climate country like Egypt, a multitude of research gaps are still to be filled, and a paradigm shift is needed to bring the subject matter from its present position in the urban planning and urban architecture domain to a more suitable position in the heart of urban ecology. Though some limitations, the study findings may assist in better planning of urban green spaces to increase their cooling potentialities.

\section{REFERENCES}

ABAAS, Z. R. 2019. Impact of development on Baghdad's urban microclimate and human thermal comfort. Alexandria Engineering Journal. 59(1): 275-290. https://doi.org/10.1016/j.aej.2019.12.040

ABD EL-GHANI M, BORNKAMM R, EL-SAWAF N. AND TURKY H. 2011. Plant species distribution and spatial habitat heterogeneity in the landscape of urbanizing desert ecosystems in Egypt. Urban Ecosystems 14: 585-616.

https://doi.org/10.1007/s11252-011-0188-1

ABD EL-GHANI M M, ABOU-EL-ENAIN M M, ABOEL-ATTA A I, HUSSEIN E A (2015) Composition, distribution patterns and habitat divergence of street trees in the Greater Cairo city, Egypt. Assiut University Bulletin for Environmental Researches 18(1): 59-91.

https://DOI: 10.21608/auber.2015.146107

ABDULATEEF, M. AND AL-ALWAN H. A. S. 2022.

The effectiveness of urban green infrastructure in reducing surface urban heat island Baghdad city as a case study. Ain Shams Engineering Journal 13(1): 101526 https://doi.org/10.1016/j.asej.2021.06.012

ABOELATA, A. 2020. Vegetation in different street orientations of aspect ratio (H/W 1:1) to mitigate UHI and reduce buildings' energy in arid climate. Building and Environment 172: 106712. https://doi.org/10.1016/j.buildenv.2020.106712

ABOELATA, A. AND SODOUDI, S. 2019. Evaluating urban vegetation scenarios to mitigate urban heat island and reduce buildings' energy in dense built-up areas in Cairo. Building and Environment 166: 106407. https://doi.org/10.1016/j.buildenv.2019.106407

ABOELATA, A. AND SODOUDI, S. 2020. Evaluating the effect of trees on UHI mitigation and reduction of energy usage in different built up areas in Cairo. Building and Environment 168: 106490. https://doi.org/10.1016/j.buildenv.2019.106490

AINA Y A, PARVEZ I M, BALOGUN A L AND ADAM E. 2021. Urban heat island effects and mitigation strategies in Saudi Arabian cities. In: Enteria N, Santamouris, M. and Eicker, U. (Eds.) Urban heat island (UHI) mitigation. Springer, Singapore. https://doi.org/10.1007/978-981-334050-3_11

AKBARI, H. AND KOLOKOTSA, D. 2016. Three decades of urban heat islands and mitigation technologies research, Energy and Buildings 133: 834-842. https://doi.org/10.1016/j.enbuild.2016.09.067

ANJOS, M. AND LOPES, A. 2017. Urban heat island and park cool island intensities in the coastal city of Aracaju, North-Eastern Brazil. Sustainability 9: 1379. https://doi.org/10.3390/su9081379

AYAD A, FAHMY M AND KAMEL W. 2019. Urban Green and Blue Infrastructure Simulation in a Changing Climate from Microclimate to Energy Consumption: A Case study in Alexandria, Egypt. Proceedings of the 16th IBPSA International Conference, 3499-3507.

https://doi.org/10.26868/25222708.2019.210676

AYYAD, N. Y. AND SHARPLES, S. 2019. Envi-MET validation and sensitivity analysis using field measurements in a hot arid climate, IOP Conference Series: Earth and Environmental Science, 329: 012040. doi:10.1088/1755-1315/329/1/012040

BALANY F, NG A W M, MUTTIL N, MUTHUKUMARAN S AND WONG M S. 2020. Green infrastructure as an urban heat island mitigation strategy: A review. Water 12(12): 3577. https://doi.org/10.3390/w12123577

BANDE L, AFSHARI A, MASRI D, MUKESH JHA M, LESLIE NORFORD L. et al. 2019. Validation of UWG and ENVI-Met models in an Abu Dhabi District, based on site measurements. Sustainability 11: 4378. https://doi.org/10.3390/su11164378

BENAS N, CHRYSOULAKIS N, AND CARTALIS C. 2017. Trends of urban surface temperature and heat island characteristics in the Mediterranean. Theoretical and Applied Climatology. 130: 807-816. https://doi.org/10.1007/s00704-016-1905-8

BENCHEIKH, H AND RCHID, A. 2012. The effects of green spaces (palme trees) on the microclimate in arid zones, case study: Ghardaia, Algeria. Energy Procedia 18: 10-20. https://doi.org/10.1016/j.egypro.2012.05.013

BIRGE D, MANDHAN S, QIU W AND BERGER A M. 2019. Potential for sustainable use of trees in hot arid regions: A case study of Emirati neighborhoods in Abu Dhabi. Landscape and Urban Planning 190: 103577. https://doi.org/10.1016/j.landurbplan.2019.05.008

BOWLER D E, BUYUNG-ALI L, KNIGHT T M AND PULLIN A S 2010. Urban greening to cool towns and cities: A systematic review of the empirical evidence. Landscape and Urban Planning. 97: 147-155. http://dx.doi.org/10.1016/j.landurbplan.2010.05.006 COSTANZO V, EVOLA G, AND MARLETTA L. 2021. Understanding heat and mass transfer at the 
urban scale. In Costanzo V, Evola G, and Marletta L. Urban Heat Stress and Mitigation Solutions. Routledge, London. https://doi.org/10.1201/9781003045922

CRANK P J, SAILOR D J, BAN-WEISS G AND TALEGHANI M. 2018. Evaluating the ENVI-met microscale model for suitability in analysis of targeted urban heat mitigation strategies. Urban Climate 26: 188-197.

https://doi.org/10.1016/j.uclim.2018.09.002

DECLET-BARRETO J, BRAZEL AJ, MARTIN CA, CHOW W T L AND HARLAN S L. 2013. Creating the park cool island in an inner-city neighborhood: heat mitigation strategy for Phoenix, AZ. Urban Ecosystems. 16: 617-635.

https://doi.org/10.1007/s11252-012-0278-8

DEGIRMENCI K, DESOUZA $\mathrm{K} C$, FIEUW $\mathrm{W}$, WATSON $\mathrm{R} T$ AND YIGITCANLAR $\mathrm{T}$. 2021.Understanding policy and technology responses in mitigating urban heat islands: A literature review and directions for future research. Sustainable Cities and Society 70: 102873. https://doi.org/10.1016/j.scs.2021.102873

DESARIO, P. A. AND GRAY, K. A. 2015. Passive systems to improve air quality and reduce heat retention in the urban environment. In: Zeman, F. (Ed.), Metropolitan sustainability: Understanding and improving the urban environment, Woodhead Publishing, Oxford.

https://doi.org/10.1533/9780857096463.3.292

EL-BARDISY W M, FAHMY M. AND EL-GOHARY G F. 2016. Climatic sensitive landscape design: Towards a better microclimate through plantation in public schools, Cairo, Egypt. Procedia-Social and Behavioral Sciences, 216: 206-216. https://doi.org/10.1016/j.sbspro.2015.12.029

ELBARDISY W M, SALHEEN M A, FAHMY M. 2021. Solar irradiance reduction using optimized green infrastructure in arid hot regions: a case study in El-Nozha District, Cairo, Egypt. Sustainability 13: 9617. https://doi.org/10.3390/su13179617

EL KENAWY A M, HEREHER M, ROBAA S M, MCCABE M F, LOPEZ-MORENO J I et al. 2020. Nocturnal surface urban heat island over Greater Cairo: Spatial morphology, temporal trends and links to land-atmosphere influences, Remote Sensing 12: 3889. https://doi.org/10.3390/rs12233889

Elmasry, L. E. 2014. Landscape Architecture in Egypt: A Plant Guidebook for Al-Azhar Park and the City of Cairo, vol. II. Shorouk Intl. Bookshop, Cairo.

ELNABAWI M., HAMZA N AND DUDEK S. 2015. Numerical modelling evaluation for the microclimate of an outdoor urban form in Cairo, Egypt, HBRC Journal 11(2): 246-251. https://doi.org/10.1016/j.hbrcj.2014.03.004

ELSADEK M, LIU B AND LIAN Z. 2019. Green façades: their contribution to stress recovery and well-being in high-density cities. Urban Forestry \& Urban Greening 46: 126446.

https://doi.org/10.1016/j.ufug.2019.126446

EMA (Egyptian Meteorological Authority). 2011. Climatological Normals for the Arab Republic of
Egypt, Surface Stations, for 1976 to 2005. Cairo, Egypt.

ESA (Egyptian Survey Authority). 1991. Cairo series, scale 1/5.000. (in Arabic)

FAHMY, M. AND SHARPLES, S. 2008. Passive design for urban thermal comfort: A comparison between different urban forms in Cairo, Egypt. In: PLEA 2008, 25th Conference on passive and low energy architecture, University College of Dublin.

FAHMY, M. AND SHARPLES, S. 2009. On the development of an urban passive thermal comfort system in Cairo, Egypt. Building and Environment 44(9): 1907-1916. https://doi.org/10.1016/j.buildenv.2009.01.010

FAHMY M, SHARPLES S AND Yahiya M. 2010. LAI based trees selection for mid latitude urban developments: A microclimatic study in Cairo, Egypt, Building and Environment, 45(2), 345-357. https://doi.org/10.1016/j.buildenv.2009.06.014

FAHMY M, EL-HADY H, MAHDY M, ABDELALIM, M F. 2017. On the green adaptation of urban developments in Egypt: Predicting community future energy efficiency using coupled outdoor-indoor simulations. Energy and Buildings 153: 241-261. https://doi.org/10.1016/j.enbuild.2017.08.008

FAHMY M, IBRAHIM Y, HANAFI E, AND BARAKAT M. 2018. Would LEED-UHI greenery and high albedo strategies mitigate climate change at neighborhood scale in Cairo, Egypt? Building Simulation 11: 1273-1288. https://doi.org/10.1007/s12273-018-0463-7

FAHMY M, KAMEL H, MOKHTAR H, ELWY I, GIMIEE A, IBRAHIM Y AND ABDELALIM M. 2019. On the development and optimization of an urban design comfort model (UDCM) on a passive solar basis at mid-latitude sites. Climate 7(1): 1. https://doi.org/10.3390/cli7010001

FAHMY M, MAHMOUD S, ELWY I AND MAHMOUD H. 2020. A review and insights for eleven years of urban microclimate research towards a new Egyptian era of low carbon, comfortable and energy-efficient housing typologies. Atmosphere 11(3): 236. https://doi.org/10.3390/atmos11030236

GALAL O M, MAHMOUD $\mathrm{H}$ AND SAILOR D . 2020a. Impact of evolving building morphology on microclimate in a hot arid climate. Sustainable Cities and Society 54: 102011. https://doi.org/10.1016/j.scs.2019.102011

GALAL O M, SAILOR D J AND MAHMOUD $\mathrm{H}$. 2020b. The impact of urban form on outdoor thermal comfort in hot arid environments during daylight hours, case study: New Aswan. Building and Environment 184: 107222. https://doi.org/10.1016/j.buildenv.2020.107222

GEORGATOU, C. AND KOLOKOTSA, D. 2016. Urban climate models. In: Santamouris, $M$ and Kolokotsa, D. Urban Climate Mitigation Techniques. Routledge, Abingdon, UK. https://doi.org/10.4324/9781315765839

GUNAWARDENA K R, WELLS M J AND KERSHAW T. 2017. Utilising green and bluespace 
to mitigate urban heat island intensity. Science of the Total Environment 584-585: 1040-1055. https://doi.org/10.1016/j.scitotenv.2017.01.158

HANAFI, A. AND DJAMEL, A. 2017. Role of the urban vegetal in improving the thermal comfort of a public place of a contemporary Saharan city. Energy Procedia 119: 139-152. https://doi.org/10.1016/j.egypro.2017.07.061

HASSAN A M, LEE H, AND YOO U. 2015. From medieval Cairo to modern Masdar City: lessons learned through a comparative study. Architectural Science $\quad$ Review $59(1)$ : 39-52. https://doi.org/10.1080/00038628.2015.1015947

JAGANMOHAN M, KNAPP S, BUCHMANN C M AND SCHWARZ N. 2016. The bigger, the better? The influence of urban green space design on cooling effects for residential areas. Journal of Environmental Quality 45(1): 134-145. https://doi.org/10.2134/jeq2015.01.0062

JAMEI E, CHAU H W, SEYEDMAHMOUDIAN M AND STOJCEVSKI A. 2021. Review on the cooling potential of green roofs in different climates. Science of the Total Environment 791: 148407.

https://doi.org/10.1016/j.scitotenv.2021.148407

KERISHNAN, P. B. AND MARUTHAVEERAN, S, 2021. Factors contributing to the usage of pocket parks: A review of the evidence. Urban Forestry \& Urban Greening 58: 126985. https://doi.org/10.1016/j.ufug.2021.126985

KHARE V R, VAJPAI A AND GUPTA D. 2021. A big picture of urban heat island mitigation strategies and recommendation for India. Urban Climate 37: 100845. ttps://doi.org/10.1016/j.uclim.2021.100845

LIMONA S S, AL-HAGLA K S AND EL-SAYAD Z T. 2019. Using simulation methods to investigate the impact of urban form on human comfort. Case study: Coast of Baltim, North Coast, Egypt. Alexandria Engineering Journal 58(1): 273-282. https://doi.org/10.1016/j.aej.2019.02.002

MAHMOUD, S. AND ISMAEEL, W. S. E. 2019. Developing sustainable design guidelines for roof design in a hot arid climate. Architectural Science Review 62(2): 507-519. https://doi.org/10.1080/00038628.2019.1665984

MAHMOUD S. H. AND GAN, T. Y. 2018. Long-term impact of rapid urbanization on urban climate and human thermal comfort in hot-arid environment. Building and Environment142: 83-100. https://doi.org/10.1016/j.buildenv.2018.06.007

MEILI N, MANOLI G, BURLANDO P, CARMELIET J, CHOW W T L et al. 2021. Tree effects on urban microclimate: Diurnal, seasonal, and climatic temperature differences explained by separating radiation, evapotranspiration, and roughness effects. Urban Forestry \& Urban Greening 58: 126970. https://doi.org/10.1016/j.ufug.2020.126970

MILLS G, FUTCHER J AND STEWART I D. 2021. The urban heat island: Its energetic basis and management. In Palme, M. and Salvati, A. Urban Microclimate Modelling for Comfort and Energy
Studies, Springer, Cham, Switzerland. https://doi.org/10.1007/978-3-030-65421-4_3

MINISTRY OF ELECTRICITY AND RENEWABLE ENERGY. 2018. The Solar Atlas of Egypt. Cairo.

MUSCO, F. (Ed.) 2016. Counteracting urban heat island effects in a global climate change scenario. Springer, Cham, Switzerland. https://doi.org/10.1007/978-3-319-10425-6

NASROLLAHI N, GHOSOURI A, KHODAKARAMI J AND TALEGHANI M. 2020. Heat-mitigation strategies to improve pedestrian thermal comfort in urban environments: A review. Sustainability 12(23): 10000. https://doi.org/10.3390/su122310000

OKE, T. R. 2006. Initial guidance to obtain representative meteorological observations at urban sites. World Meteorological Organization, Geneva, Switzerland.

OKE T R, MILLS G, CHRISTEN A AND VOOGT J A. 2017. Urban Climates, Cambridge University Press, New York, USA. DOI: 10.1017/978-1139016476

POLYDOROS A, MAVRAKOU T AND CARTALIS C. 2018. Quantifying the trends in land surface temperature and surface urban heat island intensity in Mediterranean cities in view of smart urbanization. Urban Science 2(1): 16. https://doi.org/10.3390/urbansci2010016

RIZWAN A M, DENNIS L Y C AND LIU C. 2008. A review on the generation, determination and mitigation of urban heat island. Journal of Environmental Sciences 20(1): 120-128. https://doi.org/10.1016/S1001-0742(08)60019-4

ROTH M. 2020. Understanding urban heat islands. In DOUGLAS I et al. (Eds.), The Routledge Handbook of Urban Ecology, Routledge, London. https://doi.org/10.4324/9780429506758

SANTAMOURIS, M. 2014. Cooling the cities: A review of reflective and green roof mitigation technologies to fight heat island and improve comfort in urban environments. Solar Energy 103: 682-703. https://doi.org/10.1016/j.solener.2012.07.003

SANTAMOURIS, M. 2016 Urban warming and mitigation: Actual status, impacts and challenges, In: Santamouris, M. and Kolokotsa, D. (Eds.), Urban Climate Mitigation Techniques, Routledge, Abingdon. https://doi.org/10.4324/9781315765839

SHAHRAIYNI H T, SODOUDI S, EL-ZAFARANY A, ABOU EL SEOUD T, ASHRAF H AND KRONE K. 2016. A comprehensive statistical study on daytime surface urban heat island during summer in urban areas, case study: Cairo and its new towns. Remote Sensing. 8: 643. https://doi.org/10.3390/rs8080643

STEWART, I. D. AND MILLS, G. 2021. The urban heat island: A guidebook. Elsevier, Amsterdam, Netherlands https://doi.org/10.1016/B978-0-12815017-7.00003-5

SURVEY OF EGYPT. 1946, 1959. Town series: Cairo, scale 1/5.000. (in Arabic)

TAKÁCS Á, KISS M, HOF A, TANÁCS E, GULYÁS 
Á AND KÁNTOR N. 2016. Microclimate modification by urban shade trees - an integrated approach to aid ecosystem service based decisionmaking. Procedia Environmental Sciences 32: 97109. https://doi.org/10.1016/j.proenv.2016.03.015

TSOKA S, TSIKALOUDAKI A AND THEODOSIOU

T. 2018. Analyzing the ENVI-met microclimate model's performance and assessing cool materials and urban vegetation applications: A review. Sustainable Cities and Society 43: 55-76. https://doi.org/10.1016/j.scs.2018.08.009

ULPIANI, G. 2021. On the linkage between urban heat island and urban pollution island: Three-decade literature review towards a conceptual framework. The Science of the Total Environment 751: 141727. https://doi.org/10.1016/j.scitotenv.2020.141727

WANG Y, BAKKER F, DE GROOT R AND

WÖRTCHE H. 2014. Effect of ecosystem services provided by urban green infrastructure on indoor environment: A literature review. Building and Environment 77: 88-100.

https://doi.org/10.1016/j.buildenv.2014.03.021

WILLIAM R, GOODWELL A, RICHARDSON M, LE PV, KUMAR P AND STILLWELL A S. 2016. An environmental cost-benefit analysis of alternative green roofing strategies. Ecological Engineering. 95: 1-9. https://doi.org/10.1016/j.ecoleng.2016.06.091

WONG, N. H. AND CHEN, Y. 2008. Tropical Urban Heat Islands: Climate, Buildings and Greenery, Taylor and Francis, New York. https://doi.org/10.4324/9780203931295

YU Z, YANG G, ZUO S, JØRGENSEN G, KOGA M AND VEJRE H. 2020. Critical review on the cooling effect of urban blue-green space: A threshold size perspective. Urban Forestry \& Urban Greening 49: 126630. https://doi.org/10.1016/j.ufug.2020.126630

\title{
استراتيجيات لتخفيف أثر الجزيرة الحرارية الحضرية فوق القاهرة الكبرى، مصر باستخدام ENVI-met نموذجة
}

\author{
قسم الجغر افيا، كلية الآداب، جامئ حسين القاهرة، مصر \\ الملخص العربـي
}

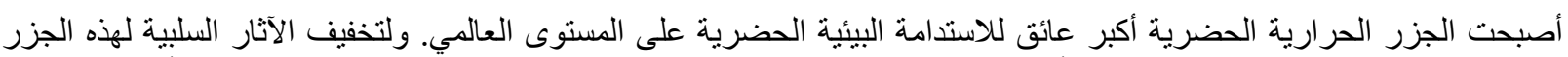

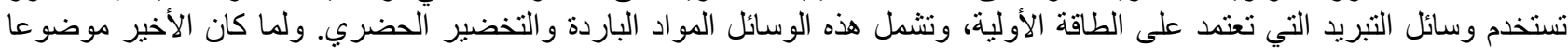

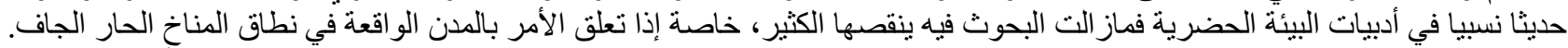

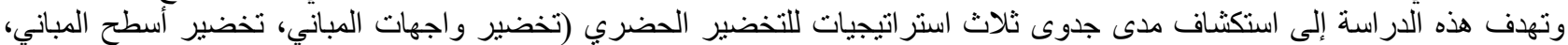

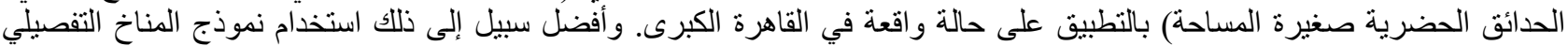
ENVI-met

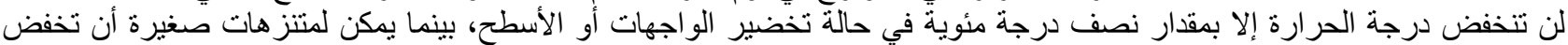

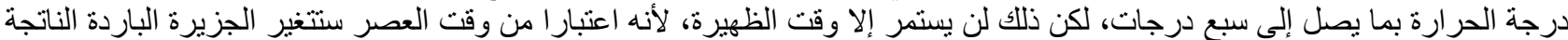
فوق الحديقة فتصبح جزيرة حارة. وقد تفيد نتائج الدر اسة مخططي المدن عند تخطيط المساحات الخضر اء لزيات لزيادة إمكاناتها في التبريد. 